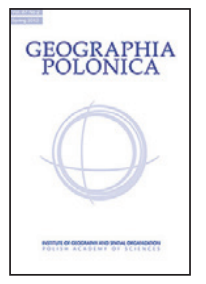

\title{
RECENT CHANGES OF THE VISUAL QUALITY OF RURAL LANDSCAPE: CASE STUDY OF SLOVAK-AUSTRIAN BORDERLAND
}

\author{
Gabriela Nováková • Dušan Šebo \\ Department of Human Geography and Demography \\ Comenius University in Bratislava \\ Mlynská dolina 1, 84215 Bratislava: Slovak Republic \\ e-mail: novakova@fns.uniba.sk
}

\begin{abstract}
This paper examines the aesthetic consequences of recent changes in the rural landscape of Slovak-Austrian borderland. By the use of panoramic pictures and their photomontage we focused on landscape structure, abandonment, suburban fabric and the presence of wind turbines in the rural landscape. A secondary aim of the study was also to recognize some factors behind the different perception preferences. Above all we would like to draw attention to the issue of aesthetic qualities of rural landscape.
\end{abstract}

\section{Key words}

rural landscape $\bullet$ visual quality $\bullet$ perception of diversity - Slovak-Austrian borderland

\section{Introduction}

Rural landscape constitutes a significant proportion of the total land area in many European countries. In this context many scholars investigate the various processes that take place in rural areas. Their foci range from ecological to socio-cultural issues. The concept of multifunctional agriculture has seemed to work as an umbrella for many of these studies since at least the 1990s. The review written by Renting et al. (2009) reveals an evident lack of approaches dealing with the visual quality of agricultural landscapes in the context of multi-functionality. The aim of this article is to highlight some aesthetic consequences of recent changes in the rural landscapes as well as some factors that influence perception differences. Our results should support recognition of the aesthetic consequences of selected features of the recent rural landscape. 


\section{Study area and aim of the study}

The rural landscape in the Slovak-Austrian borderland $^{1}$ (Fig. 1) is a territory that has in some way undergone significant transformation during recent years. This is mostly due to the suburbanization pressure on towns and villages within daily commuting distance of the Slovak capital city. This pressure influences rural areas not only in Slovakia, but also in the nearby rural areas of Austria and Hungary. Changes caused by suburbanization absorb not only the arable land of the Danubian Lowland, but the historical vineyards are also disappearing. They are often replaced by shrubs and young forest in some places, simply because of lack of interest in viticulture. The typical scenario is to let the vineyards grow over and sell them profitably later (see Lieskovský et al. 2013).

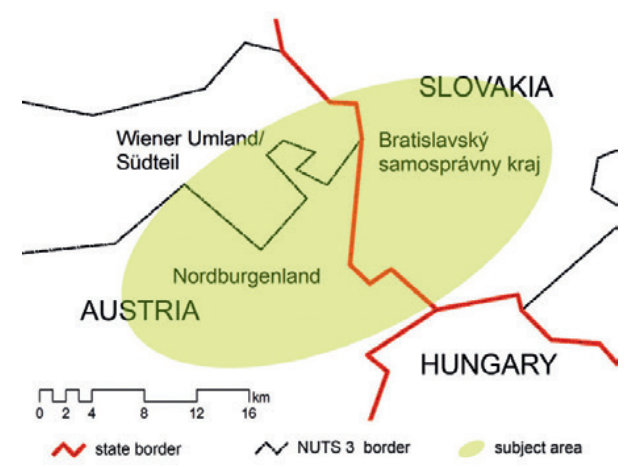

Figure 1. Subject area

Source: (c) EuroGeographics for the administrative boundaries.

Even before these circumstances arose, the Slovak rural landscape had been dramatically changed by the collectivization of agriculture in the second half of the twentieth century. Small scale farming was replaced by a socialist cooperative agricultural system. As a consequence, small plots were united into large

1 The area between Haidboden and the Hundsheimer Berge mountains or Leitha Gebirge mountains in Niederösterreich and the contact area of the Podunajská pahorkatina hill country and Malé Karpaty Mountains in Slovakia. blocks of agricultural land. Since 2007, when Slovakia joined the Schengen Area, some Slovak citizens moved to the Austrian borderland. They built new housing with suburban features that gradually modified the rural character of the landscape on both sides of the border.

Wind turbines are another significant features shaping the rural landscape in the Slovak-Austrian borderland mostly over the last decade (IEA 2010).

All the changes mentioned above - suburban development, abandonment of farming followed by succession, the changes in landscape structure and the presence of wind turbines - have a certain impact on aesthetic appreciation of rural landscape. The aim of our study was to reveal the perception attributes of these changes.

\section{Theoretical background and methodical approach}

Approaches applied in the landscape visual quality research are generally classified into (Sandler \& Carlson 1982; Daniel 2001; Otahel' 2003; Ot́ahel' \& Hlavatá 2010²):

1. Objective (expert) approach when quantifiable landscape parameters are measured (e.g. Crawford 1994; Otahel' 1999; Dramstad et al. 2006);

2. Subjective (perception-based) assessing individual preferences and attitudes to landscape. Research subjects also include analysis of the motives for such attitudes (e.g. Keisteri 1990; Dakin 2003).

By this classification, our study adopted the approaches of the second group when the changes in the visual quality of the landscape were studied via the perception of a group of respondents. According to Daniel (2001), perception-based assessments, unlike the expert approaches, have generally achieved high levels of reliability. Daniel also notices that the perceptual judgements (based on viewing

\footnotetext{
2 Ot́ahel' and Hlavatá (2010) also distinguish objective-subjective approaches that analyse acoustic, aromatic and dynamic landscape properties.
} 
photographs, computer images or the actual landscapes) do not automatically provide valid indications of true landscape quality. The study of Lange (2001) on the other hand proves that computer-generated $3 \mathrm{D}$ visualizations of landscapes are valid representations of the real landscape. Similarly, using photographs enabled understanding of the preferred settings, landscape elements and spatial configurations that informed people's choices (Jorgensen 2011). Recently we have observed the use of photomontage techniques that help to understand the changes of landscape visual quality (Lothian 2008; Lindemann-Matthies et al. 2010; Tempesta 2010).

The effects of the natural and man-made landscape elements via photographs were studied by Arriaza et al. (2004), who found out that the visual quality of rural landscape increases with the degree of its naturalness (wilderness). The percentage of vegetation cover, the amount of water, the presence of mountains, and the colour contrasts, as well as the effects of well-maintained anthropic elements, are viewed as positive as well. Lewis (2008) also used photographs with simulations of various approaches to landscape management, studying the perception of landscape by the rural community in northwest British Columbia. Tempesta's work (2010), which studied the perception of individual elements of cultural landscape and how such perception differed into three groups of respondents - children, university students and adults, has been inspiring for this study. Tempesta (2010) worked with photomontages - he added or removed certain elements to and from photographs and evaluated their effects by use of mathematical models. Although the author claims that these models do not have a good explanatory capability, he identified elements which increase or reduce the aesthetic landscape quality. Perception preferences of respondents naturally differ and the author tried to explain these differences.

In our study panoramic photographs were used for the assessment of implications attributable to potential and real changes. Each picture captures a certain landscape segment.

\section{Methods and Sampling}

Panoramic pictures were used to represent a certain landscape segment ${ }^{3}$. In total, 40 photographs were arranged into a slideshow which was presented to 180 university students of geography ${ }^{4}$. We assumed some appreciation of the aesthetic landscape quality in this group of respondents. Apart from calibration, this methodology step agrees with the one applied by Tempesta (2010). Quantitative results were analysed using statistical software Statgraphics Plus. A matched pairs t-test (Paired-Sample-Comparison) was performed to establish the statistical significance of the differences between the perceptions of two samples of photographs. We compared differences between means of points assigned to two groups of photographs of the same landscape, for example differences between the mean of points assigned to 4 photographs of landscape with wind turbines and the mean of points assigned to 4 photographs of the same landscapes, but without wind turbines. A description of how these adaptations were applied to individual cases for each monitored phenomenon follows four types of changes.

\section{Changes of landscape structure}

We assumed that a more structured agricultural landscape is more attractive. Our interest was in the rate of changed attractiveness

3 Using the Photoshop CS5 we simulated the potential changes in a particular landscape segment. For the sake of calibration the photographs were first shown in $4 \mathrm{sec}$. sequence and subsequently in $8 \mathrm{sec}$. variation. The images belonging to the same type of landscape were separated by at least five photographs of other type of landscape. Students evaluated each image by values from 1 to 10 (where 1 was given to the least preferred image and 10 was awarded to the most preferred one) and they were asked to utilize the scale's full range.

4 Our sample consisted of 180 students of geography (aged between 18 and 28 years), 56\% of them were women. They were divided into four groups of similar size. The arrangement of the pictures (see below) was different for each group. The total number of completed questionnaires was 177. Three respondents did not answer the question about the type of their residence (urban/rural) or some additional questions. 
caused by the change of structure. All photographs were taken in the early spring and late autumn of 2012 with the aim of eliminating the effect of grown crops. Consequently, the changes in images only concerned the area of individual field blocks. Such adaptation of photographs resulted in three categories of images. The first category contained those of a more structured landscape where arable land consisted of a number of smaller fields. The next categories contained agricultural landscape consisting of large blocks of fields where some blocks were ploughed while others were covered by offshoots of winter crops, green manure crops or grass.

As the effect of the ploughed land generally reduces the aesthetic quality of landscape
(Marangon \& Tempesta 2008; LindemannMatthies et al. 2010), an attempt was made to maintain a balanced ratio of fields covered by the vegetating greenery and the freshly ploughed land in the first category of images (Fig. 2). An additional two categories were treated as two variants of large field blocks large plots of ploughed land (Fig. 3) and large plots of green areas (Fig. 4).

\section{Abandonment}

Another surveyed type of changes in the rural landscape was abandonment followed by natural succession and afforestation. In this area only vineyards were studied as they are the most threatened by this problem mainly

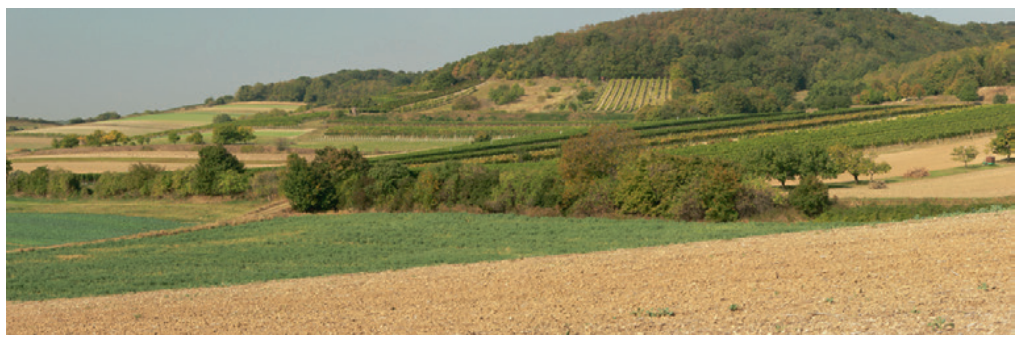

Figure 2. More structured landscape

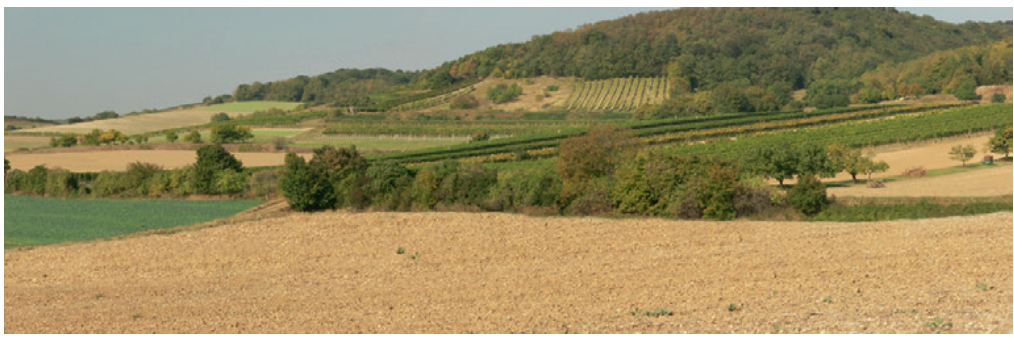

Figure 3. Landscape consisting of large blocks (ploughed variant)

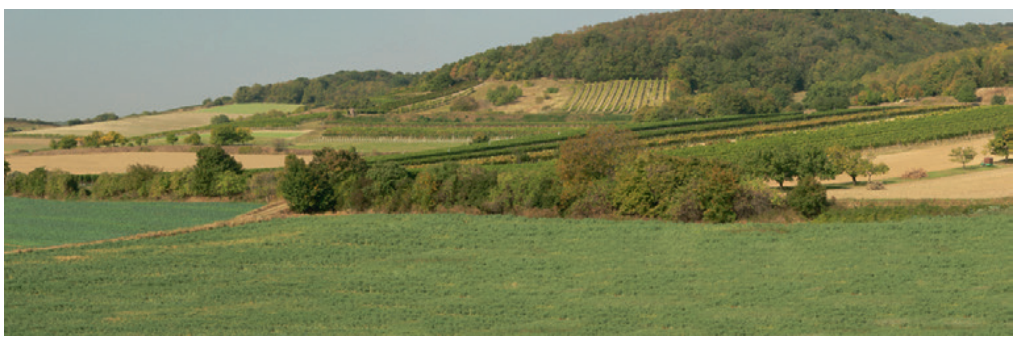

Figure 4. Landscape consisting of large blocks (green variant) 


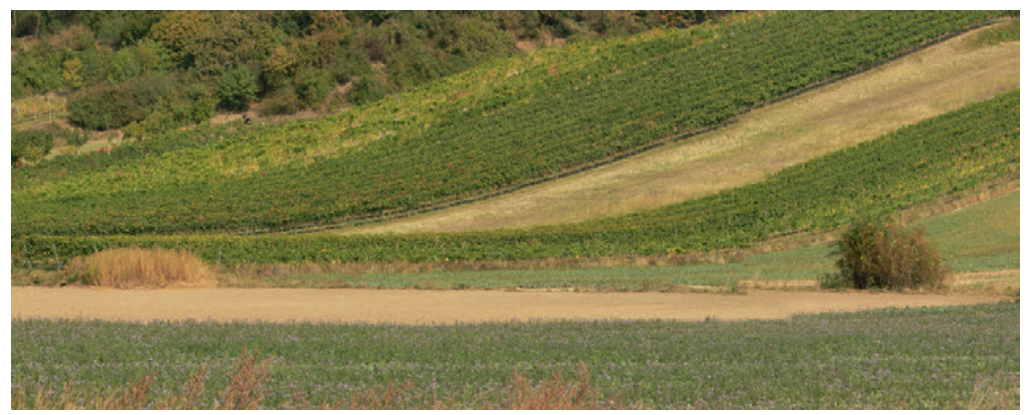

Figure 5. Vineyard landscape



Figure 6. Vineyard landscape - partially changed by self-sowing

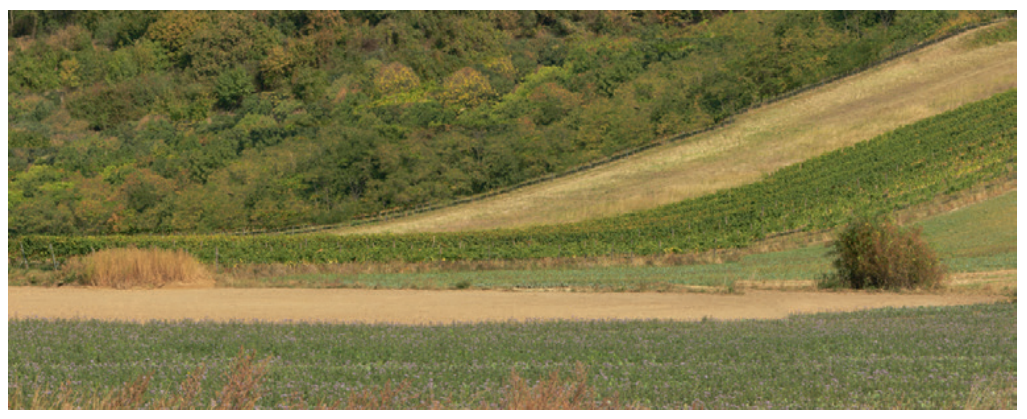

Figure 7. Vineyard landscape - partially afforested

in the Slovak part of the study area (Fig. 5). By using photomontages selected vineyards were replaced by areas typical for the initial stage of the natural succession, hereinafter rising ${ }^{5}$ succession (Fig. 6). Again it was assumed that such change affects the aesthetic quality of landscape while the rate of such

\footnotetext{
5 By rising succession we indicate the phase when vineyards are gradually replaced by scrub species (e.g. Sambucus, Crataegus, Rubus, Prunus, Cornaceae).
}

effect was the subject of research. The change of the aesthetic landscape quality during the final stages of succession, when associations of weeds, grasses and herbs are replaced by forest, was another point of our interest. Consequently, the change in the aesthetic landscape quality in the cases where part of vineyards were replaced by forest was also surveyed (Fig. 7). Similarly to the previous scope, four scenes (in total twelve images) were evaluated. 


\section{Suburban fabric}

The uncontrolled suburban growth in recent years has been threatening the cultural landscape of the concerned territory. The extent to which this phenomenon causes changes in the perceived aesthetic landscape quality was investigated. Four landscape scenes ${ }^{6}$ were evaluated. In two of them the existing construction was removed and replaced by the reconstructed landscape as it likely existed before the intervention, while in the other two segments, semidetached houses were inserted into the landscape as a new element. It was important for us to avoid capturing bare buildings. In each case they were set in a certain landscape context. An example of rural landscape segment with/without houses typical for suburban areas is presented in Figures 8 and 9.

\section{Wind turbines}

The last sphere of the aesthetic changes in landscape treated in this study was the presence of wind turbines in farmland. "Ten years ago, wind turbines were not important but now they have a major impact on many scenes" (Bell 2004: viii). The effect of wind turbines on the aesthetic quality of landscape has received a considerable amount of attention while the approaches differ depending on applied methods and types of respondents (for more details see for example Molnarova et al. 2012). Similar works involved with the subject (e.g. Lothian 2008; Zoellner et al. 2008; Cetkovský \& Nováková 2009; Frantál \& Kučera 2009) confirm the opinion that the perception of wind turbines in landscape always depends on a number of factors and a local approach must be applied when investigating the perception of these structures. In this study the effect of wind turbines in irregular arrangement was studied. Bell (2004) used a wind turbine as an example of a vertical line form in space. Lines can cause visual forces and tension depending on how they are positioned. A single object (a wind turbine) can be easily be positioned in the landscape. But a larger number of wind turbines are more difficult to accommodate, as they must relate to both landscape and to each other (Bell 2004).



Figure 8. Agricultural landscape with new suburban houses

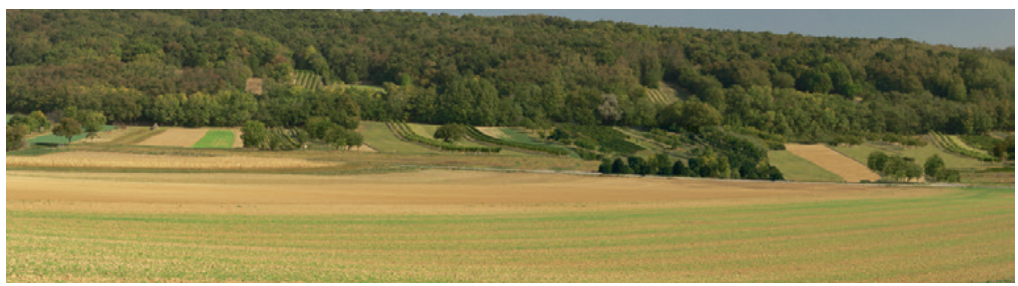

Figure 9. Agricultural landscape without any buildings

\footnotetext{
6 In total eight photographs were compared where four images represented landscape with houses and four without them.
} 


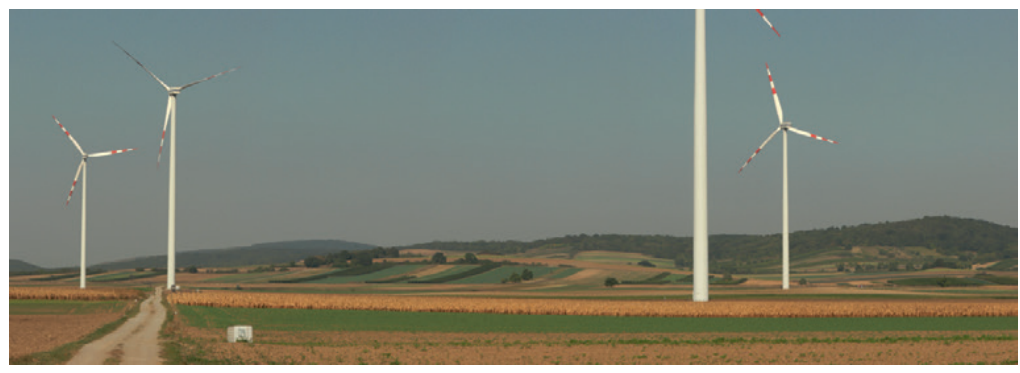

Figure 10. Agricultural landscape with wind turbines

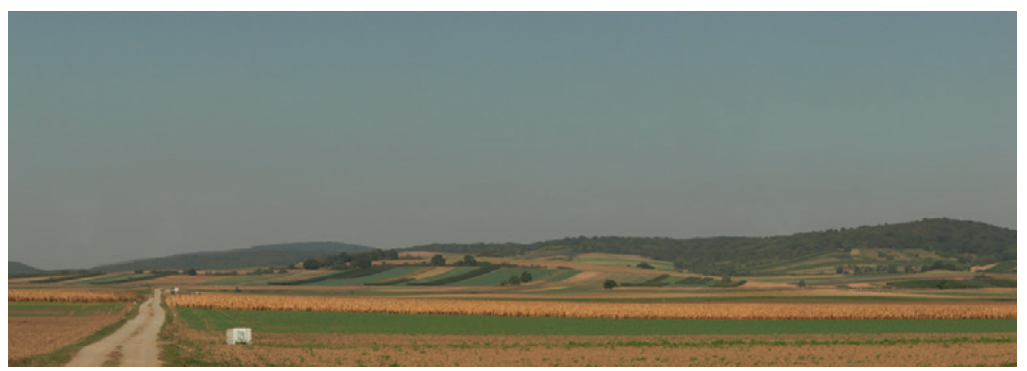

Figure 11. Agricultural landscape without any turbines

So we used photographs with more than one turbine. The adaptations consisted of the removal of these towers and remaking of the vacant spots on the photographs with stress on the background (Fig. 10, 11). Again, we evaluated 4 scenes (8 images).

\section{Diversity of visual landscape quality preferences}

The assessment of changes in visual landscape quality is a complex process influenced by many factors. Its aspects have been investigated by many scholars (Frantál \& Kučera 2009; van der Horst 2009; Ode et al. 2010; Siwek 2011). The perception of landscape (geographical space) is formed by evolution and learning, which means, it is predetermined by culture (Siwek 2011). The partial aim of this research was also to find out how certain changes and interventions into landscape modify its aesthetic quality and to what extent these visual-aesthetic preferences are determined by the values of the respondent. We also investigated if there is any connection between visual preferences in the field of rural landscape alternations and the environment where respondents spend most of their lives - urban or rural.

The value preferences of individual respondents were investigated by a set of complementing questions that were answered by respondents after finishing the evaluation of all photographs. Each question had two possible answers to choose. The wording and meaning of questions is explained as follows:

1. What is more important for agricultural landscape/our agriculture?

a) To preserve more structured agricultural land for the purpose of biodiversity at the expense of a less profitable (lucrative) production, which might be compensated by adequate agricultural subsidies.

b) To prefer the more effective agricultural production, while the support for biodiversity should be concentrated in the natural areas protected by law.

The intention was to find out whether the visual-aesthetic preferences for structured landscapes are influenced by respondent's 
preferences either for environmental farming or for the economic approach. It was assumed that students with environmental preferences would perceive the more structured landscape as finer than students who would prefer intensive production.

2. The preservation of cultural landscape should be as important as the preservation of natural areas protected by law.
a) YES
b) NO

The intention was to find out whether respondents who respect the significance of cultural landscape conservation would perceive abandonment of land and succession more negatively than those who do not consider conservation of cultural landscape as important as that of the legally protected natural areas.

3. What is more important?

a) To be able to shape my own plot and dwelling according to my individual ideas.

b) My own dwelling should be architecturally in tune with the surrounding landscape.

This question investigated whether the presence of typical suburban houses in rural landscape is generally evaluated negatively or if there are some differences according to various preferences.

4. Is your knowledge about 'energy systems' good?

('energy systems' here means - possible energy sources, positive and negative effects of energy supply technologies, measures supporting energy savings)
a) YES
b) $\mathrm{NO}$

The aim of this question was to find out whether the visual-aesthetic perception of wind turbines varies depending on the respondent's knowledge of the energy system. It was assumed that the attitude to wind turbines of a person who is basically familiar with the subject is different (more positive) from that of an uninstructed person. The study of Frantál and Kučera (2009) also revealed that the level of knowledge about the given wind turbine project is the most significant factor for their perception in the landscape.

5. Global warming is:

a) mostly a natural phenomenon

b) mostly induced by humans

This was again a simplified attempt to verify the assumption that students who consider global warming as a prevailingly man-induced process and are aware of the hazard represented by greenhouse gases, are prone to respect the presence of wind turbines in the landscape in accord with Culek (2007), who asserts "The assessment of the impact of wind turbine construction on the landscape character cannot be separated from the assessment of the expected contribution of wind turbines to power engineering and prevention of global warming" (Cetkovský \& Nováková 2009: 31).

\section{Results}

\section{Changes in landscape structure}

According to our findings there are significant differences in the appreciation of landscape with various landscape structures, although the land use phase of particular plots is very important. The least attractive was ploughed large-plots landscape. Only 31.6\% of respondents considered it more attractive in comparison to a small-plots (mosaic) landscape which was more interesting for $58.2 \%$ of students (10.2\% of respondents did not identify any distinction between these two categories) (Tab. 1). Noteworthy findings in this category are that $70.9 \%$ of those who preferred mosaic landscape would support agro-biodiversity at the expense of a less profitable production and $39.3 \%$ of those who appreciated ploughed large-plots landscape would give priority to intensive agriculture at the expense of agro-biodiversity stimulation (Tab. 2).

The most attractive was the 'green version' of the large-plots landscape which was preferred by $59.9 \%$ of respondents when compared with mosaic landscape, and by $68.4 \%$ of students when compared with ploughed large-plots one (Tab. 3, 4).

We used the matched pairs t-test to test the null hypothesis that the mean of differences 
Table 1. The attractiveness of small-plots (mosaic) landscape in comparison with ploughed large-plots landscape

\begin{tabular}{|l|c|r|r|r|r|r|}
\hline \multirow{2}{*}{$\begin{array}{c}\text { Differences } \\
\text { in evaluation }\end{array}$} & \multicolumn{4}{|c|}{ Residence of respondents } & \multicolumn{3}{c|}{ Total } \\
\cline { 2 - 7 } & \multicolumn{2}{|c|}{ Urban } & \multicolumn{2}{|c|}{ Rural } & \multicolumn{2}{c|}{} \\
\cline { 2 - 7 } & sum & $\%$ & sum & $\%$ & sum & $\%$ \\
\hline 1$)$ & 63 & 63.6 & 40 & 51.3 & 103 & 58.2 \\
$2)$ & 10 & 10.1 & 8 & 10.2 & 18 & 10.2 \\
$3)$ & 26 & 26.3 & 30 & 38.5 & 56 & 31.6 \\
Total & 99 & 100.0 & 78 & 100.0 & 177 & 100.0 \\
\hline
\end{tabular}

Notes: 1) Small-plots (mosaic) landscape is more attractive.

2) No differences.

3) Ploughed large-plots landscape is more attractive.

Table 2. The attractiveness of more structured landscape in comparison with ploughed large-plots landscape. Answers to question Nr. 1: "What is more important for agricultural landscape/our agriculture?"

\begin{tabular}{|l|c|c|c|c|c|c|}
\hline \multirow{2}{*}{\begin{tabular}{c}
\multirow{2}{*}{$\begin{array}{c}\text { Differences } \\
\text { in evaluation }\end{array}$} \\
\cline { 2 - 7 }
\end{tabular}} & \multicolumn{2}{|c|}{ Answers to question No. 1: } & \multicolumn{2}{c|}{ Total } \\
\cline { 2 - 7 } & sum & $\%$ & sum & $\%$ & sum & $\%$ \\
\hline 1$)$ & 73 & 70.9 & 30 & 29.1 & 103 & 100.0 \\
$2)$ & 11 & 61.1 & 7 & 38.9 & 18 & 100.0 \\
$3)$ & 34 & 60.7 & 22 & 39.3 & 56 & 100.0 \\
Total & 118 & 66.7 & 59 & 33.3 & 177 & 100.0 \\
\hline
\end{tabular}

Notes: 1) Small-plots (mosaic) landscape is more attractive.

2) No differences.

3) Ploughed large-plots landscape is more attractive.

a. To preserve the more structured agricultural landscape for the purpose of biodiversity at the expense of a less profitable production.

b. To prefer the more effective agricultural production and the support of biodiversity should be concentrated on the natural areas protected by law.

Table 3. The attractiveness of more structured landscape in comparison with green large-plots landscape

\begin{tabular}{|c|c|c|c|c|c|c|}
\hline \multirow{3}{*}{$\begin{array}{l}\text { Differences } \\
\text { in evaluation }\end{array}$} & \multicolumn{4}{|c|}{ Residence of respondents } & \multirow{2}{*}{\multicolumn{2}{|c|}{ Total }} \\
\hline & \multicolumn{2}{|c|}{ Urban } & \multicolumn{2}{|c|}{ Rural } & & \\
\hline & sum & $\%$ & sum & $\%$ & sum & $\%$ \\
\hline 1) & 26 & 26.3 & 23 & 29.5 & 49 & 27.7 \\
\hline 2) & 14 & 14.1 & 8 & 10.2 & 22 & 12.4 \\
\hline 3) & 59 & 59.6 & 47 & 60.3 & 106 & 59.9 \\
\hline Total & 99 & 100.0 & 78 & 100.0 & 177 & 100.0 \\
\hline
\end{tabular}

Notes: 1) Small-plots (mosaic) landscape is more attractive.

2) No differences.

3) Green large-plots landscape is more attractive. 
Table 4. The attractiveness of green large-plots landscape in comparison with ploughed large-plots landscape

\begin{tabular}{|l|r|r|r|r|r|r|}
\hline \multirow{2}{*}{$\begin{array}{c}\text { Differences } \\
\text { in evaluation }\end{array}$} & \multicolumn{4}{|c|}{ Residence of respondents } & \multicolumn{3}{c|}{ Total } \\
\cline { 2 - 7 } & \multicolumn{3}{|c|}{ Urban } & \multicolumn{2}{c|}{ Rural } & \multicolumn{2}{c|}{} \\
\cline { 2 - 7 } & sum & $\%$ & sum & $\%$ & sum & $\%$ \\
\hline 1$)$ & 71 & 71.7 & 50 & 64.1 & 121 & 68.4 \\
$2)$ & 9 & 9.1 & 7 & 9.0 & 16 & 9.0 \\
$3)$ & 19 & 19.2 & 21 & 26.9 & 40 & 22.6 \\
Total & 99 & 100.0 & 78 & 100.0 & 177 & 100.0 \\
\hline
\end{tabular}

Notes: 1) Green large-plots landscape is more attractive.

2) No differences.

3) Ploughed large-plots landscape is more attractive.

between the evaluation of photographs with small-plots (mosaic) landscape and photographs with green large-plots landscape equals 0.0 (there are no differences) versus the alternative hypothesis that the mean of that is less than 0.0. Since the p-value for this test is less than $0.01(p=0.000)$, we can reject the null hypothesis at the $99.0 \%$ confidence level. There is a statistically significant difference between the evaluation of photographs with small-plots (mosaic) landscape and photographs with green large-plots landscape (the respondents evaluated green large-plots landscape as more attractive).

The $p$-value for the t-test in the case of differences between evaluation of photographs with ploughed large-plots landscape and photographs with green large-plots landscape was also less than 0.01 ( $p=0.000)$ (respondents evaluated green large-plots landscape as more attractive).

The matching of students who preferred the green large-plots landscape and those appreciating a more mosaic landscape also detects some differences in the answers to the first question. Although both groups would support agro-biodiversity at the expense of more profitable agriculture, there are certain differences between them. Only $60.4 \%$ of those preferring green large-plots landscape would support agro-biodiversity at the expense of more profitable agriculture, while $73.5 \%$ of those preferring mosaic landscape are familiar with such an attitude. This suggests that people who are more conscious of the importance of agro-biodiversity appreciate a more structured landscape type (Tab. 5).

\section{Abandonment}

The more significant differences emerged from a comparison of rising succession with both alternative categories wherein rising succession appears as a feature lowering the visual quality of rural landscapes. In the case of comparison of rising succession and forest variant, the result was $34.7 \%$ to $52.8 \%$ in favour of forest $12.5 \%$ of respondents did not identify any notable differences). A comparison of the rising succession with vineyards also confirmed a lower aesthetic appreciation of abandonment at a ratio of $26.9 \%$ to $62.1 \%$ (11.0\% of respondents did not identify any notable differences).

The matched pairs t-test was used to test the null hypothesis that the mean of differences between evaluation of photographs with vineyards and photographs, where vineyards were replaced by areas typical for the initial stage of the secondary succession equals 0.0 (there are no differences) versus the alternative hypothesis that the mean of that is greater than 0.0 (vineyards are more attractive). Since the p-value for this test is less than 0.01 ( $p=0.000)$, we can reject the null hypothesis at the $99.0 \%$ confidence level. There 
Table 5. The attractiveness of more structured landscape in comparison with green large-plots landscape. Answers to question No. 1: "What is more important for agricultural landscape/our agriculture?"

\begin{tabular}{|c|c|c|c|c|c|c|}
\hline \multirow{3}{*}{$\begin{array}{l}\text { Differences } \\
\text { in evaluation }\end{array}$} & \multicolumn{4}{|c|}{ Answers to question No. 1 : } & \multirow{2}{*}{\multicolumn{2}{|c|}{ Total }} \\
\hline & \multicolumn{2}{|c|}{ a) } & \multicolumn{2}{|c|}{ b) } & & \\
\hline & sum & $\%$ & sum & $\%$ & sum & $\%$ \\
\hline 1) & 36 & 73.5 & 13 & 26.5 & 49 & 100.0 \\
\hline 2) & 18 & 81.8 & 4 & 18.2 & 22 & 100.0 \\
\hline 3) & 64 & 60.4 & 42 & 39.6 & 106 & 100.0 \\
\hline Total & 118 & 66.7 & 59 & 33.3 & 177 & 100.0 \\
\hline
\end{tabular}

Notes: 1) Small-plots (mosaic) landscape is more attractive.

2) No differences.

3) Green large-plots landscape is more attractive.

a. To preserve the more structured agricultural landscape for the purpose of biodiversity at the expense of a less profitable production.

b. To prefer the more effective agricultural production and the support of biodiversity should be concentrated on the natural areas protected by law.

is a statistically significant difference between the evaluation of photographs with vineyards and photographs with landscape in the initial stage of the secondary succession (respondents evaluated vineyards as more attractive). The $p$-value for t-test in a case of differences between evaluation of photographs with landscape in the initial stage of the succession and photographs, where vineyards were replaced by forest, was less than 0.01 ( $p=0.005$ ) (respondents evaluated photographs with forests as more attractive). These results clearly prove that the visual quality of landscape decreases with rising succession.

Almost equal attractiveness is obvious in matching rural landscape without signs of succession (it is more attractive for $49.5 \%$ of respondents) with landscape where part of the vineyards were replaced by forest (it was more attractive for $37.4 \%$ of respondents). As the p-value for t-test was 0.01, there is not a statistically significant difference between evaluation of photographs of vineyards and photographs with forest at the $99.0 \%$ confidence level. Therefore these results indicate that vineyard landscape has the same aesthetic qualities as natural landscape.

The answers to question No. 2 show that there are $74.7 \%$ respondents, who consider cultural landscape protection as important as protection of natural areas and that there are no relevant differences in perceiving abandonment between those who consider cultural landscape protection as important as protection of natural areas and those who do not support this idea. So in this case our findings did not support the assumption that students who support the idea of cultural landscape protection would perceive abandonment markedly negatively.

\section{Suburban fabric}

Investigating the effect of suburban houses clearly confirmed that new buildings in a rural landscape reduce its aesthetic qualities. Overall $81.4 \%$ of respondents evaluated landscape without buildings more positively $(79.8 \%$ of the students with urban backgrounds and $83.3 \%$ students with rural background) (Tab. 6). In this case there is not statistically significant difference in the assessment of aesthetic qualities of rural landscape with/without semidetached buildings among students who have spent most of their life in the rural in comparison with those of urban areas $(p=0.183)$.

Some differences in the perception of buildings in the landscape emerged from the answers to the third question. $75 \%$ of students who considered the design of their dwelling 
to be more important, appreciated rural landscape without buildings. Students who preferred the context of surrounding landscape evaluated landscape without buildings as more attractive (85.8\% of them). Similarly, only $28.5 \%$ of students, who preferred landscape without buildings, attributed higher importance to their own ideas in the design of their own dwelling, while $43.3 \%$ of the students who preferred landscape with buildings shared this idea.

\section{Wind turbines}

Although the presence of wind turbines in rural landscapes globally decreases its aesthetic appreciation, this finding was not so evident as we expected seeing that 'only' $52.5 \%$ of respondents consider wind turbines to be an element decreasing landscape visual qualities. Moreover there are significant differences in evaluation that occur according to the respondent's background. Those students who spend most of their life in urban areas considered landscape with wind turbines equally attractive as landscape without turbines $(46.5 \%$ to $44.4 \%)$. However, in the case of students with rural background, $66.7 \%$ of them appreciated landscape without wind turbines as more attractive (Tab. 7).

According to our investigation, knowledge about energy systems (question No. 4) does not increase appreciation of wind turbines in the rural landscape. But it is worthwhile to notice that three quarters $(73.9 \%)$ of the students who preferred landscape with turbines consider global warming to be a phenomenon mostly induced by humans (question No. 5).

Table 6. The attractiveness of agricultural landscape with/without construction

\begin{tabular}{|l|r|r|r|r|r|r|}
\hline \multirow{2}{*}{$\begin{array}{c}\text { Differences } \\
\text { in evaluation }\end{array}$} & \multicolumn{4}{|c|}{ Residence of respondents } & \multicolumn{3}{c|}{ Total } \\
\cline { 2 - 7 } & \multicolumn{2}{|c|}{ Urban } & \multicolumn{2}{c|}{ Rural } & \multicolumn{2}{c|}{} \\
\cline { 2 - 7 } & number & $\%$ & number & $\%$ & number & $\%$ \\
\hline 1$)$ & 79 & 79.8 & 65 & 83.3 & 144 & 81.4 \\
$2)$ & 2 & 2.0 & 1 & 1.3 & 3 & 1.7 \\
$3)$ & 18 & 18.2 & 12 & 15.4 & 30 & 16.9 \\
Total & 99 & 100.0 & 78 & 100.0 & 177 & 100.0 \\
\hline
\end{tabular}

Notes: 1) Agricultural landscape without buildings is more attractive.

2) No differences.

3) Agricultural landscape with buildings is more attractive.

Table 7. The attractiveness of agricultural landscape with/without wind turbines

\begin{tabular}{|l|c|c|c|c|c|r|}
\hline \multirow{2}{*}{$\begin{array}{c}\text { Differences } \\
\text { in evaluation }\end{array}$} & \multicolumn{4}{|c|}{ Residence of respondents } & \multicolumn{3}{c|}{ Total } \\
\cline { 2 - 7 } & \multicolumn{3}{|c|}{ Urban } & \multicolumn{2}{c|}{ Rural } & \multicolumn{2}{c|}{} \\
\cline { 2 - 7 } & number & $\%$ & number & $\%$ & number & $\%$ \\
\hline 1$)$ & 41 & 44.4 & 52 & 66.7 & 93 & 52.5 \\
$2)$ & 12 & 12.1 & 4 & 5.1 & 16 & 9.0 \\
$3)$ & 46 & 46.5 & 22 & 28.2 & 68 & 38.5 \\
Total & 99 & 100.0 & 78 & 100.0 & 177 & 100.0 \\
\hline
\end{tabular}

Notes: 1) Agricultural landscape without wind turbines is more attractive.

2) No differences.

3) Agricultural landscape with wind turbines is more attractive. 


\section{Discussion results}

In the presented study we researched the aesthetic consequences of some recent changes in the rural landscape of the Slovak-Austrian borderland. The analysed trends are common in the rural areas of many European countries (MacDonald et al. 2000; Siedentop \& Fina 2012; Silva \& Klagge 2013). As a drawback of the used method we identified some difficulties with modelling the original environment of the areas that were building-up already. The visualization of the original environment was created by graphical adjustment according to surroundings. An objection could be taken to our respondents. Although most of them are familiar with the study area they are not inhabitants directly affected by the changes. In spite of this our findings could be interpreted in the following sense:

In the field of landscape structure landscape with a higher share of greenery has the best visual quality. The importance that people attribute to support for agro-biodiversity influences the rate of aesthetic appreciation of landscape with higher agro-biodiversity features.

Although the assumption that the abandoned agricultural landscape has lower visual quality is generally accepted, there is a lack of academic studies supporting and deeply analysing this idea. Benjamin et al. (2007) already confirmed that abandoned agricultural landscape is least appreciated by the owners of farmland. They also distinguished woodlot as the most attractive type of land use in the farmland. We found out that a well maintained cultural landscape has the same aesthetic qualities as a natural landscape.

Another feature definitely reducing the aesthetic qualities of farmland is new housing with suburban attributes. Although this finding may stand against the suburban development in rural landscape it does not resolve the situation in areas with strong demand for housing as the study area definitely is. Planners should pay more attention to attributes such as legibility of open space, texture of buildings and prominence of trees and not only in such cases (Zhang \& Lin 2011) .

Our study has found out that the importance which respondents attributed to opportunities to shape their own properties and dwellings was an important factor in their general acceptance of suburban houses in the rural landscape. Let us put it differently. People with strong predetermined conception of living space do not harmonize their dwelling with their surroundings. This knowledge should also be taken into account when the population is integrated into the landscape planning process.

Wind turbines are not such a disturbing element in the rural landscape as we expected. On the other hand, the rural background compared with urban background of respondents is a factor that influences acceptance of turbines in the landscape. Deeper explanation of this fact definitely requires more investigation. Van der Horst and Vermeylen (2011) suggest in more rural areas in the UK, for example, differences of attitude between locals and newcomers towards the allocation of renewable energy technologies in the landscape. Locals incline to see these technologies as a development with possible job and income opportunities while newcomers used to perceive them as a threat to the landscape. However, the situation in Slovakia seems to be different. The rapid changes of socio-economic formations during the 20th century in Central and Eastern Europe (see Palang et al. 2006) may explain certain differences between Slovakia and the UK.

In addition to birdkill, noise and flicker the aesthetic impact of wind farms is the most negative attribute of their installation in the landscape (Bishop \& Miller 2007). The visual disamenity of wind turbines decreases roughly in line with the distance from them (Ladenburg 2009; Krueger et al. 2012). However visual acceptance of turbines can differ according to the age (Bishop \& Miller 2007) or more

\footnotetext{
${ }^{7}$ It is necessary to say that the aesthetic quality of farmland with new housing will be likely higher when trees and gardens will environ the houses after a few years.
} 
subtle social factors, such as environmental consciousness (Westerberg et al. 2013). This knowledge gradually deepens our understanding of the factors 'behind' the visual impact of wind turbines but investigation in this field is far from the end.

Our aim was not to give an explicit answer with regard to monitored landscape features and their aesthetic impacts. More than this we would like to draw attention to the issue of visual quality of rural or agricultural landscape and some factors behind it. According to Eurostat (2010) utilised agricultural areas account for $37.2 \%$ of the total area of the 27 EU members. Despite the fact that millions of us are in daily contact with this type of landscape it is surprising that agricultural policy generally does not pay attention to this issue. Maybe this could be the next step in the transition to a more multifunctional European agriculture landscape.

Finally, we focused on a borderland. According to the European Landscape Convention (ELC) this area should be managed by means of a joint landscape programme

\section{References:}

Arriaza M., Cañas-Ortega J.F. Cañas-Madueño, J.A. Ruiz-Aviles, P., 2004. Assessing the visual quality of rural landscapes. Landscape and Urban Planning, vol. 69, no. 1, pp. 115-125.

BeLL, S., 2004. Elements of visual design in the landscape. Second edition. New York: Spon Press, https://www.moodle.uevora.pt/1314/ pluginfile.php/46413/mod_resource/content/1/ simon\%20bell.pdf [5 May 2016].

Benjamin K., Bouchard A., Domon G., 2007. Abandoned farmlands as components of rural landscapes: An analysis of perceptions and representations. Landscape and Urban Planning, vol. 83, no. 4, pp. 228-244.

BisHop I.D., Miller D.R., 2007. Visual assessment of off-shore wind turbines: The influence of distance, contrast, movement and social variables. Renewable Energy, vol. 32, no. 5, pp. 814-831.
(Council of Europe 2000). Although Austria did not sign the ELC its practical experiences with landscape planning are on high level. Our wish is that the presented study will contribute to effective management of the common landscape.

\section{Acknowledgement}

The article is based on data and information gained thanks to the financial support of the following projects: VEGA-grant No. 2/0111/12 entitled "Selected geographical aspects of environmental developments in Slovakia and its regions in the international context" and APVV-grant No. APV-0018-12 entitled "Human Geographical and Demographic Interactions, Nodes and Contradictions within a Time-space Network".

Editors' note:

Unless otherwise stated, the sources of tables and figures are the authors', on the basis of their own research.

Cetrovský S, Nováková E., 2009. Assessment of the impact of wind turbines on landscape character: Implication for landscape planning. Moravian Geographical Reports, vol. 17, no. 2, pp. 28-34.

Council of Europe, 2000. European Landscape Convention: Florence: 20.10.2000. Strasbourg: Council of Europe Publishing, http://www.coe. int/t/dg4/cultureheritage/heritage/landscape/ Publications/Convention-Txt-Ref_en.pdf [10 December 2013].

Crawford D., 1994. Using remotely sensed data in landscape visual quality assessment. Landscape and Urban Planning, vol. 30, no. 1-2, pp. 71-81.

CULEK M., 2007. Vybrané problémy větrných elektráren. Aktuální problémy ochrany krajinného rázu 2007. Praha: ČVUT v Praze a Zahradnická fakulta MZLU v Lednici, 2008, pp. 26-35. 
DANIEL T.C, 2001. Whither scenic beauty? Visual landscape quality assessment in the 21 st century. Landscape and Urban Planning, vol. 54, no. 1-4, pp. 267-281.

DAKIN S., 2003. There's more to landscape than meets the eye: Towards inclusive landscape assessment in resource and environmental management. Canadian Geographer, vol. 47, no. 2, pp. 185-200.

Dramstad W.E., Sundli TVeit M., Fjellstad W.J., Fry G.L.A., 2006. Relationships between visual landscape preferences and map-based indicators of landscape structure. Landscape and Urban Planning, vol. 78, no. 4, pp. 465-474.

Eurostat, 2010. Agricultural census 2010 - provisional results. Eurostat: Statistics explained, http://epp.eurostat.ec.europa.eu/statistics_ explained/index.php/Agricultural_census_ 2010___provisional_results [20 June 2016].

FrANTÁL, B., KUČERA P., 2009. Impacts of the operation of wind turbines as perceived by residents in concerned areas. Moravian Geographical Reports, vol. 17, no. 2, pp. 35-45.

IEA, 2010. Austria-annual report. International Energy Agency, http://www.ieawind.org/annual_ reports_PDF/2010/Austria.pdf [20 June 2016].

JoRgEnSEN A., 2011. Beyond the view: Future directions in landscape aesthetics research. Landscape and Urban Planning, vol. 100, no. 4, pp. 353-355.

KEISTERI T., 1990. The study of changes in cultural landscapes. Fenia, vol. 168, no. 1, pp. 31-115.

Krueger A.D., Parsons G.R. Firestone J., 2012. Valuing the visual disamenity of offshore wind power projects at varying distances from the shore: An application on the Delaware shoreline. Land Economics, vol. 87, no. 2, pp. 268-283.

LADENBURG J., 2009. Visual impact assessment of offshore wind farms and prior experience. Applied Energy, vol. 86, no. 3, pp. 380-387.

LANGE E., 2001. The limits of realism: Perceptions of virtual landscapes. Landscape and Urban Planning, vol. 54, nos. 1-4, pp. 163-182.

Lieskovský J., Kanka R., Bezák P., Štefunková D., Petrovič F., Dobrovodská M., 2013. Driving forces behind vineyard abandonment in Slovakia following the move to a market-oriented economy. Land Use Policy, vol. 32, pp. 356-365.

LEWIS J.L., 2008. Perceptions of landscape change in a rural British Columbia community.
Landscape and Urban Planning, vol. 85, no. 1, pp. 49-59.

Lindemann-Matthies P., Briegel R., Schüpbach B., JUNGE X., 2010. Aesthetic preference for a Swiss alpine landscape: The impact of different agricultural land-use with different biodiversity. Landscape and Urban Planning, vol. 98, no. 2, pp. 99-109.

LOTHIAN A., 2008. Scenic perceptions of the visual effects of wind farms on South Australian landscapes. Geographical Research, vol. 46, no. 2, pp. 196-207.

MacDonald D., Crabtree J.R., Wiesinger G., Dax T., Stamou N., Fleury P., Gutierrez LazplTA J., GIBON A., 2000. Agricultural abandonment in mountain areas of Europe: Environmental consequences and policy response. Journal of Environmental Management, vol. 59, no. 1, pp. 47-69.

Marangon F., Tempesta T., 2008. The economic evaluation of the rural landscape in Italy. Paper submitted to the European Consortium on Landscape Economics in the 3rd Workshop on Landscape Economics, Versailles, Paris. 2008. pp. 29-30, http://www.ceep-europe.org/workshop_files/workshop47_116.pdf [14 December 2012].

Molnarova K., Sklenicka P., Stiborek J., Svobodova K., Salek M., Brabec E., 2012. Visual preferences for wind turbines: Location, numbers and respondent characteristics. Applied Energy, vol. 92, pp. 269-278.

Ode A., Hagerhall C.M., Sang N., 2010. Analysing visual landscape complexity: Theory and application. Landscape Research, vol. 35, no. 1, pp. 111-131.

OŤAHEL' J., 1999. Visual landscape perception: landscape pattern and aesthetic assessment. Ekologia Bratislava, vol. 18, no. 1, pp. 63-74.

Ö̌AHEL' J., 2003. Visual quality of the landscape: Approaches to analysis. Ekologia Bratislava, vol. 22, no. 2, pp. 150-160.

Ơ̌Ahel' J., HlavatÁ Z., 2010. Krajina a jej vnímanie: prístupy k analýze. Folia Geographica, vol. 40, no. 16 , pp. 23-35.

Palang H., Printsmann A., Gyuró É.K., Urbanc M., Skowronek E., Woloszyn W., 2006. The forgotten rural landscapes of Central and Eastern Europe. Landscape Ecology, vol. 21, no. 3, pp. 347-357. 
Renting H., Rossing W.A.H., Groot J.C.J., Van der Ploeg J.D., Laurent C., Perraud D., Stobbelaar D.J., Van ItTersum M.K., 2009. Exploring multifunctional agriculture. A review of conceptual approaches and prospects for an integrative transitional framework. Journal of Environmental Management, vol. 90, suppl. 2, pp. 112-123.

Sandler B., Carlson A.A. (eds.), 1982. Environmental aesthetics: Essays in interpretation. Western Geographical Series, 20, Victoria, B.C., Canada: Department of Geography. University of Victoria.

Siedentop S., Fina S., 2012. Who sprawls most? Exploring the patterns of urban growth across 26 European countries. Environment and Planning $A$, vol. 44, no. 11, pp. 2765-2784.

Silva P.C., Klagge B., 2013. The evolution of the wind industry and the rise of Chinese firms: From industrial policies to global innovation networks. European Planning Studies, vol. 21, no. 9, pp. 1341-1356.

SIWEK T., 2011. Percepce geografického prostoru. Praha: Česká geografická společnost.
TEMPESTA T., 2010. The perception of agrarian historical landscapes: A study of the Veneto plain in Italy. Landscape and Urban Planning, vol. 97, no. 4, pp. 258-272.

VAN DER HORST D., 2009. Spatial planning of wind turbines and the limits of "objective" science. Moravian geographical reports, vol. 17, no. 2, pp. 46-51.

VAN DeR Horst D., Vermeylen S., 2011. Spatial scale and social impacts of biofuel production. Biomass and Bioenergy, vol. 35, no. 6, pp. 2435-2443.

Westerberg V., Jacobsen J.B., Lifran R., 2013. The case for offshore wind farm, artificial reefs and sustainable tourism in the French Mediterranean. Tourism Management, vol. 34, nos. 2-3, pp. 172-183.

ZHANG H., LIN S.H., 2011. Affective appraisal of residents and visual elements in the neighbourhood: A case study in an established suburban community. Landscape and Urban Planning, vol. 101, no. 1, pp. 11-21.

Zoellner J., Schweizer-Ries P., Wemheuer CH., 2008. Public acceptance of renewable energies: Results from case studies in Germany. Energy Policy, vol. 36, no. 11, pp. 4136-4141.
(C) Gabriela Nováková • Dušan Šebo

(C) Geographia Polonica

(C) Institute of Geography and Spatial Organization

Polish Academy of Sciences • Warsaw • 2016
Article first received • December 2015 Article accepted • July 2016 